\title{
Development and Chemical Characterization of Pequi Pericarp Flour (Caryocar brasiliense Camb.) and Effect of in vitro Digestibility on the Bioaccessibility of Phenolic Compounds
}

\author{
Bárbara O. Santos, ${ }^{\oplus a}$ Maurício Tanigaki, ${ }^{\oplus a}$ Mauro R. Silva, ${ }^{\circledR b}$ Ana Luiza C. C. Ramos, ${ }^{\oplus a}$ \\ Renata A. Labanca, ${ }^{\oplus a}$ Rodinei Augusti, ${ }^{\odot c}$ Júlio O. F. Melo, ${ }^{\oplus *, d}$ Jacqueline A. Takahashi ${ }^{\odot}$ \\ and Raquel L. B. de Araújo ${ }^{\circledR a}$ \\ ${ }^{a}$ Departamento de Alimentos, Universidade Federal de Minas Gerais (UFMG), \\ 31270-901 Belo Horizonte-MG, Brazil \\ ${ }^{b}$ Departamento de Nutrição, Pontifícia Universidade Católica de Minas Gerais (PUC-Minas), \\ 30640-070 Belo Horizonte-MG, Brazil \\ 'Departamento de Química, Universidade Federal de Minas Gerais (UFMG), \\ 31270-901 Belo Horizonte-MG, Brazil \\ ${ }^{d}$ Departamento de Ciências Exatas e Biológicas, Universidade Federal de São João Del-Rei (UFSJ), \\ 35701-970 Sete Lagoas-MG, Brazil
}

\begin{abstract}
The pequi pericarp corresponds to the largest portion of the fruit and has a high nutritional value, but it is discarded as an agro-industrial residue. The present study aimed to prepare and characterize flours from the pequi pericarp in terms of their proximate composition, its antioxidant potential before and after the in vitro digestibility process and chemical profile, aiming at the full use of this fruit. The samples of pequi pericarp flours from the cities of Sete Lagoas, Paraopeba and Felixlândia were analyzed. The profile of chemical compounds present in the flours was determined using paper spray mass spectrometry. The in vitro simulated digestion technique was used to verify the stability of the phenolic compounds and the maintenance of the antioxidant capacity of the samples. The flours from the pequi pericarp showed to have higher levels of protein, ash and dietary fiber, compared to the data described in the literature for the pulp of the fruit. The analysis of paper spray mass spectrometry allowed the identification of 46 chemical compounds including amino acids, sugars, organic acids and phenolic compounds. The analysis of the main components showed that there was no chemical variation among the fruits from the cities studied. Through the in vitro digestibility technique, it was possible to observe an increase in the bioaccessibility of phenolic compounds, contributing to increase the already significant antioxidant capacity of the samples. It was concluded that the pequi pericarp flour has the potential to be used as a food ingredient due to the high bioaccessibility of its bioactive compounds, capable of reducing the risk of developing diseases caused by oxidative stress.
\end{abstract}

Keywords: agro-industrial waste, pequi pericarp, antioxidant capacity, paper spray, principal component analysis

\section{Introduction}

Brazil is the country with the largest biodiversity in the world, with more than $70 \%$ of all species of fauna and flora existing today. Pequi (Caryocar brasiliense Camb.) is a native fruit of the Brazilian Cerrado cultivated in several

*e-mail: onesiomelo@gmail.com

Editor handled this article: Emanuel Carrilho (Associate) states in the northeast, southeast and central-west regions of the country, with an annual production of approximately 27,000 tons. ${ }^{1,2}$ During the processing of the fruit, the pericarp (peel) is discarded as agro-industrial waste. However, this part of the fruit has potential use in human consumption due to the high content of dietary fiber, carotenoids and phenolic compounds with significant antioxidant capacity. ${ }^{1,3,4} \mathrm{Few}$ applications for the pequi pericarp have been reported in the literature so far, such as its use in the development of 
breads $^{5}$ and cookies, ${ }^{6}$ as a source of high methoxylation pectin $^{7}$ and as an antimicrobial in reduced sodium Minas Frescal goat cheeses. ${ }^{8}$

Studies ${ }^{910}$ have been developed in order to characterize agro-industrial wastes that have bioactive compounds important for physiological functions and to establish alternatives for the efficient, economical and safe use of these organic materials, as an alternative to their disposal. The use of these wastes can add value to agro-industrial by-products, generate jobs and also reduce environmental pollution.

The transformation of agro-industrial waste into coproducts such as flour promotes the reduction of free water and, consequently, minimizes the chemical and microbiological reactions that normally occur in fresh food. In addition, the reduction in water content causes the concentration of substances such as bioactive compounds, dietary fibers and minerals; reduces post-harvest losses and ensures greater ease of incorporation into different food formulations. ${ }^{11,12}$

Phenolic compounds are known to have high antioxidant capacity and their consumption has been associated with a reduction in the risk of developing diseases such as cancer, diabetes and cardiovascular diseases. ${ }^{13,14}$ However, one of the main limiting factors of its beneficial action in the body is the bioaccessibility, which depends on digestive stability and food release..$^{15,16}$

Bioaccessibility measures possible changes in compounds during the digestion stages, and is determined as the amount of a compound that is released from its matrix, making it available for absorption. ${ }^{17}$ Research on the bioaccessibility of polyphenols is important, since only compounds released from food are potentially bioavailable and are in a position to have beneficial effects. ${ }^{15}$

For the characterization of the chemical composition of foods, including flours, instrumental analytical techniques such as gas chromatography (GC), high performance liquid chromatography (HPLC) and capillary electrophoresis (CE) can be used. However, these techniques generally require laborious pre-treatment of the samples ${ }^{18-20}$ and the techniques of ambient ionization have been preferred, because they do not require samples pre-treatment. In addition, they are simpler and have a low analytical cost, enabling quick and sensitive analyses in different matrices. ${ }^{19,21}$

Among the ambient ionization techniques, paper spray mass spectrometry (PS-MS) has been used to analyze the chemical composition of complex matrices. In this method, the sample is added to a triangular chromatographic paper along with a solvent and a high strength electric field is applied to carry out the ionization. There is then the formation of a spray with charged droplets that travels towards the entrance of the mass spectrometer to be analyzed. ${ }^{22,23}$ Due to its characteristics, the PS-MS technique has been used in studies of several food matrices such as teas, ${ }^{18,24}$ red wine, ${ }^{25}$ fruits and vegetables, ${ }^{20,26-28}$ grains, ${ }^{29}$ alcoholic beverages,${ }^{21,30}$ coffee,${ }^{31}$ extra-virgin olive oil $^{32}$ and energy drinks, ${ }^{33}$ among others.

The objective of the present study was to develop and characterize flours prepared from the pequi pericarp in terms of their chemical composition, as well as to verify the bioaccessibility of phenolic compounds and changes in the antioxidant capacity of these samples after the in vitro digestibility process. In addition, to identify the chemical profile of the samples using PS-MS and to differentiate the pequi pericarp flours from three different cities through principal component analysis (PCA).

\section{Experimental}

\section{Reagents}

The standards Folin-Ciocalteu, 2,2'-azinobis(3-ethyl-benzothiazoline-6-sulfonic acid) (ABTS), 2,2-diphenyl-1-picryl-hydrazil (DPPH), 6-hydroxy2,5,7,8-tetramethylchromo-2-carboxylic acid (Trolox), 2,4,6-tris(2-pyridyl)-s-triazine (TPTZ), the enzymes $\alpha$-amylase, porcine pepsin, pancreatin and bile salts were purchased from Sigma-Aldrich (São Paulo, SP, Brazil). Analytical grade reagents such as acetone, methanol and hydrochloric acid were purchased from Vetec (São Paulo, SP, Brazil). HPLC grade acetonitrile was purchased from JT Baker (Phillipsburg, NJ, USA) and chromatographic paper of brand Whatman (Little Chalfont, Buckinghamshire, UK).

\section{Sample preparation}

The ripe pequi fruits were collected on the ground, during the 2018 harvest, from 15 pequi trees located in three cities in the state of Minas Gerais (Brazil): Sete Lagoas (latitude $19^{\circ} 28^{\prime} 48^{\prime \prime}$ and longitude $44^{\circ} 11^{\prime} 57^{\prime \prime}$ ), Paraopeba (latitude $19^{\circ} 13^{\prime} 12^{\prime \prime}$ and longitude $44^{\circ} 26^{\prime} 38^{\prime \prime}$ ) and

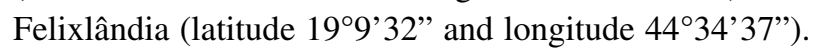
After collection, the fruits of each pequi tree $(1.5 \mathrm{~kg}$ per pequi tree) were packed separately in polystyrene boxes and transported to the Food Chemistry laboratory of the Food Department of the Faculty of Pharmacy of the Federal University of Minas Gerais, where they were inspected and those with intact pericarp were selected. They were then sanitized by rinsing with running water followed by sanitization using an aqueous solution of sodium hypochlorite at $200 \mathrm{mg} \mathrm{L}^{-1}$ for $15 \mathrm{~min}$. 
The fruits were cut manually in their longitudinal diameter, separating the endocarps from the pericarps and the latter were crushed in a food processor (Fast Juice NKS, TSK-445, Itapevi, SP, Brazil). After this stage, the crushed samples of each pequi orchard were transferred separately to stainless steel trays and dried in an oven with air circulation (Fanem, 315 SE, São Paulo, SP, Brazil) at $45^{\circ} \mathrm{C}$ for approximately $15 \mathrm{~h}$. Afterwards, the samples were crushed in a knife mill (Tecnal TE020, Piracicaba, SP, Brazil) and sieved in 42 mesh sieves, thus obtaining 15 pequi pericarp flours ( $150 \mathrm{~g}$ per pequi tree). Then, $20 \mathrm{~g}$ of each of the flours $(n=15)$ were packed separately in metal sachets that were sealed and stored in a freezer at $-18{ }^{\circ} \mathrm{C}$ until the chemical profile analysis by PS-MS was carried out. The rest of the flour from each pequi tree was homogenized forming a pool for each collection city (Sete Lagoas, Paraopeba and Felixlândia, $n=3$ ), and was packed in metal sachets, which were sealed and stored in a freezer at $-18{ }^{\circ} \mathrm{C}$ until analysis of the chemical composition, total phenolic compounds and antioxidant capacity.

\section{Chemical composition}

The moisture, ash, protein, lipid and soluble and insoluble fiber contents of the pequi pericarp flours were determined according to the methodology proposed by the Association of Official Analytical Chemists ${ }^{34}$ and the available carbohydrate content was determined by difference.

\section{Extracts production}

The extraction of the samples was carried out according to the methodology described by Rufino et al.${ }^{35}$ Flour extracts from each of the 15 pequi trees $(n=15)$ were prepared to be used in the chemical profile analysis by PS-MS. Extracts from the flour pools from each of the three cities $(n=3)$ were also prepared for the determination of total phenolic compounds and antioxidant capacity. For this, $0.25 \mathrm{~g}$ of flour was weighed in $2 \mathrm{~mL}$ Eppendorf tubes and $1 \mathrm{~mL}$ of methanol/ water solution $(50: 50, \mathrm{v} / \mathrm{v})$ was added. The tubes were vortexed for $30 \mathrm{~s}$ and incubated in the dark for $1 \mathrm{~h}$ at room temperature. Subsequently, centrifugation was performed at $25,406 \times \mathrm{g}$ for $30 \mathrm{~min}$ and the supernatants were collected in $5 \mathrm{~mL}$ volumetric flasks. Then, $1 \mathrm{~mL}$ of acetone/water solution $(70: 30, \mathrm{v} / \mathrm{v})$ was added to the precipitate, with a new incubation and centrifugation. The obtained supernatant was mixed with the previous and the flask volume was made up with distilled water.

Flour extracts from each of the 15 pequi trees $(n=15)$ were prepared to be used in the chemical profile analysis by
PS-MS. Extracts from the flour pools of each of the three cities $(n=3)$ were also prepared for the determination of total phenolic compounds and antioxidant capacity.

\section{Chemical profile by PS-MS}

The analysis of the chemical profile of the flour extracts from each of the 15 pequi tree was carried out according to the methodology proposed by Silva et al. ${ }^{20}$ (Figure 1). An LCQ Fleet mass spectrometer (Thermo Scientific, San José, CA, USA) was used coupled to a paper spray ionization source and the analyses were performed in triplicate in the positive and negative ionization modes. The experimental conditions were: mass range: $\mathrm{m} / \mathrm{z} 100$ to 1000 ; source voltage: $3.0 \mathrm{kV}$ (positive and negative mode); capillary voltage $40 \mathrm{~V}$; transfer tube temperature $275{ }^{\circ} \mathrm{C}$; voltage $120 \mathrm{~V}$ tube lenses; distance from the tip of the chromatographic paper to the input of the spectrometer: $0.5 \mathrm{~cm}$; collision energy for fragmentation: 15 to $40 \mathrm{eV}$.

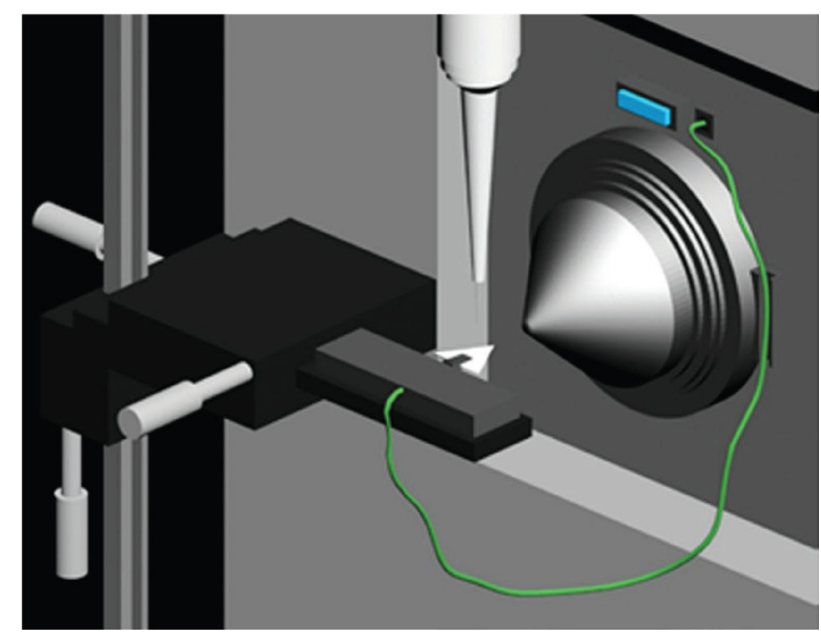

Figure 1. Diagram of the paper spray of ionization source (figure from reference 20 with CC-BY attribution).

To perform the analyses, $2.0 \mu \mathrm{L}$ of the sample extracts were added to the chromatographic paper (cut into the shape of an equilateral triangle $1.5 \mathrm{~cm}$ in length) that was supported on a metal clip connected to a high voltage source of mass spectrometer. ${ }^{36}$ Then, $40.0 \mu \mathrm{L}$ of acetonitrile were applied to the chromatographic paper and the voltage source was connected for data acquisition. The ions and their fragments were used to identify the compounds based on the data described in the literature. ${ }^{20}$

\section{Total phenolic compounds and antioxidant capacity}

The extracts obtained from the flour pools in each of the three cities were used to determine the content of total 
phenolic compounds following the method described by Singleton et al. ${ }^{37}$ and for the evaluation of antioxidant capacity by the ferric reducing antioxidant power (FRAP) and ABTS methods according to the methodology suggested by Rufino et al. ${ }^{35}$ and the DPPH method according to the methodology proposed by AOAC. ${ }^{38}$

\section{Bioaccessibility}

The in vitro digestibility process of the samples was carried out according to the methodology described in a standardized protocol prepared by Minekus et al. ${ }^{39}$ The analysis is divided into three sequential steps: oral phase, gastric phase and intestinal phase. In each phase, enzymes and solutions with appropriate concentrations of electrolytes and specific $\mathrm{pH}$ are used, which mimic the human salivary fluid, gastric fluid and intestinal fluid and simulate the digestive process.

After the stages of the simulated digestion process, the samples were centrifuged and the supernatants were collected for the determination of total phenolic compounds and antioxidant capacity, according to the aforementioned methods, to assess their bioaccessibility.

\section{Statistical analysis}

The results of the analysis of proximate composition, total phenolic compounds and antioxidant capacity were subjected to one-way analysis of variance (ANOVA) and the Tukey's test $(p<0.05)$ to evaluate the means. To compare the results of the phenolic compounds and the antioxidant capacity of the samples before and after in vitro digestibility, the Student's $t$-test $(p<0.05)$ was used. The mass spectra were analyzed by the Xcalibur software and the average PS-MS spectra in the positive and negative ionization modes were determined using a Microsoft Excel 2010 $0^{40}$ spreadsheet. The analysis of the main components was performed in the MATLAB software, ${ }^{41}$ with the aid of the PLS Toolbox. ${ }^{42}$

\section{Results and Discussion}

\section{Chemical composition}

The results obtained for the chemical composition of the pequi pericarp flour pools of each city are shown in Table 1.

Moisture content of pequi pericarp flour pools from Sete Lagoas (8.56\%), Paraopeba (7.90\%) and Felixlândia $(9.37 \%)$ differed statistically $(p<0.05)$. However, all samples are below the maximum limit of $15 \%$ recommended in the Brazilian legislation for flours. ${ }^{43}$ The lipid levels found for all flours were low, which makes them less susceptible to lipid oxidation and contributes to better conservation of the flours. Protein contents did not differ statistically among samples $(p>0.05)$ and varied between 5.21 and $5.86 \%$. Such results corroborate those reported by Soares Júnior et al. ${ }^{6}$ who indicated a protein content of $5.59 \%$ for pequi pericarp flour. The ashes contents of the samples were between 2.58 and $3.17 \%$. These results are slightly higher than those obtained by Leão et al. ${ }^{1}$ who reported a $2.34 \%$ ash content for pequi pericarp flours. Pequi pericarp flours showed high levels of insoluble dietary fiber that varied between 38.00 and $44.37 \%$. Such results were higher than those obtained by Leão et al., ${ }^{1}$ using the same methodology, which indicated a $33.94 \%$ insoluble dietary fiber content. These authors also reported soluble dietary fiber content of $9.38 \%$. These results are also lower than those obtained in the present study (range from 13.08 to $14.83 \%$ ).

Dietary fiber has several benefits for human health, including a reduction in serum cholesterol and glucose levels and a reduced risk of developing some chronic noncommunicable diseases such as hypertension, diabetes, obesity, cardiovascular diseases, cancer and gastrointestinal disorders. In addition, dietary fiber also acts to improve the immune system. ${ }^{44,45}$ Considering the estimated averages for total dietary fiber, all flours obtained can be considered rich in dietary fiber, since Brazilian legislation ${ }^{46}$ classifies foods with at least $6 \%$ total dietary fiber as fiber-rich foods.

Table 1. Chemical composition of the pequi pericarp flours on a dry basis

\begin{tabular}{|c|c|c|c|}
\hline \multirow{2}{*}{ Parameter } & \multicolumn{3}{|c|}{ Sample } \\
\hline & Sete Lagoas & Paraopeba & Felixlândia \\
\hline Lipids / (g $\left.100 \mathrm{~g}^{-1}\right)$ & $1.42^{\mathrm{a}} \pm 0.10$ & $1.43^{\mathrm{ab}} \pm 0.04$ & $1.41^{\mathrm{a}} \pm 0.11$ \\
\hline Proteins / (g $\left.100 \mathrm{~g}^{-1}\right)$ & $5.41^{\mathrm{a}} \pm 0.29$ & $5.21^{\mathrm{a}} \pm 0.17$ & $5.86^{\mathrm{a}} \pm 0.30$ \\
\hline Ashes / (g $\left.100 \mathrm{~g}^{-1}\right)$ & $2.59^{\mathrm{a}} \pm 0.04$ & $2.58^{\mathrm{a}} \pm 0.19$ & $3.17^{\mathrm{b}} \pm 0.31$ \\
\hline Insoluble fibers / (g $\left.100 \mathrm{~g}^{-1}\right)$ & $44.24^{\mathrm{a}} \pm 0.06$ & $44.37^{\mathrm{b}} \pm 0.22$ & $38.00^{\mathrm{ac}} \pm 0.07$ \\
\hline Soluble fibers / $\left(\mathrm{g} 100 \mathrm{~g}^{-1}\right)$ & $13.08^{\mathrm{a}} \pm 0.44$ & $13.32^{\mathrm{ab}} \pm 0.32$ & $14.83^{\mathrm{bc}} \pm 0.42$ \\
\hline Carbohydrates available / $\left({\left.\mathrm{g} 100 \mathrm{~g}^{-1}\right)}^{-1}\right.$ & 33.26 & 33.09 & 36.73 \\
\hline
\end{tabular}

Averages followed by the same letter on the same line do not differ, using the Tukey's test $(\alpha=0.05 ; n=3)$. 
The results of the chemical composition demonstrated the superiority of the pequi pericarp flours compared to the fruit pulp in terms of protein $(1.79 \%)$, ash $(0.61 \%)$ and total dietary fiber $(5.89 \%) .{ }^{47}$ These results demonstrate the nutritional value of this waste that can be incorporated into different food formulations, minimizing the waste of nutrients and generating a new food source.

\section{Chemical profile by PS-MS}

Examples of PS-MS spectra of extracts from pequi pericarp flours in the positive and negative ionization modes analyzed in the present study are shown in Figure 2. The substances identified in the pequi pericarp flours from the 15 pequi trees were amino acids, sugars, organic acids and several types of phenolic compounds.

\section{Fingerprints obtained in positive ionization mode}

The possible compounds identified through the fingerprints on the (+)PS-MS are shown in Table 2.

An amino acid (L-arginine), a sugar (sucrose), a phenolic acid (ellagic acid xyloside) and five flavonoids (crisoeriol, gallocatechin, rhamnetin, delfinidine-
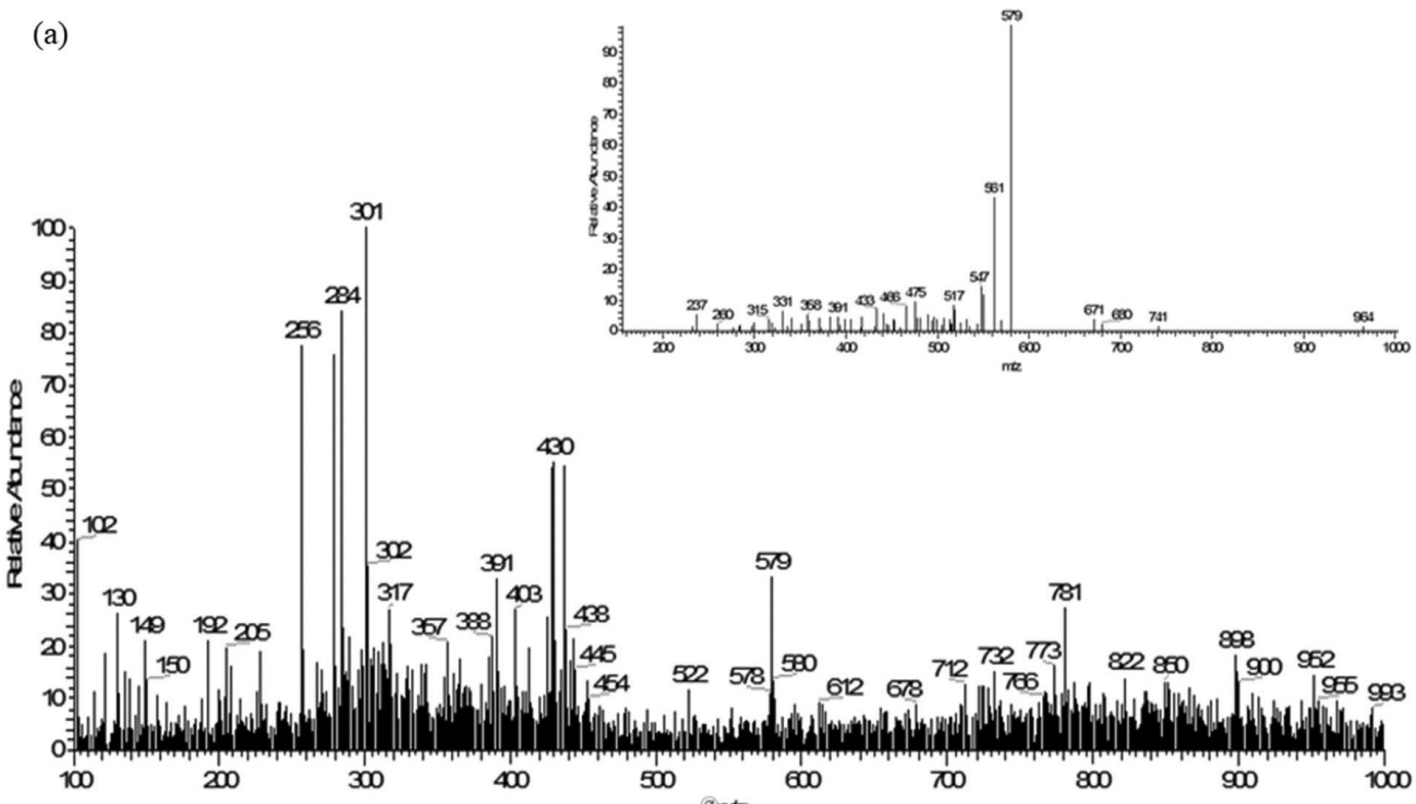

(b)

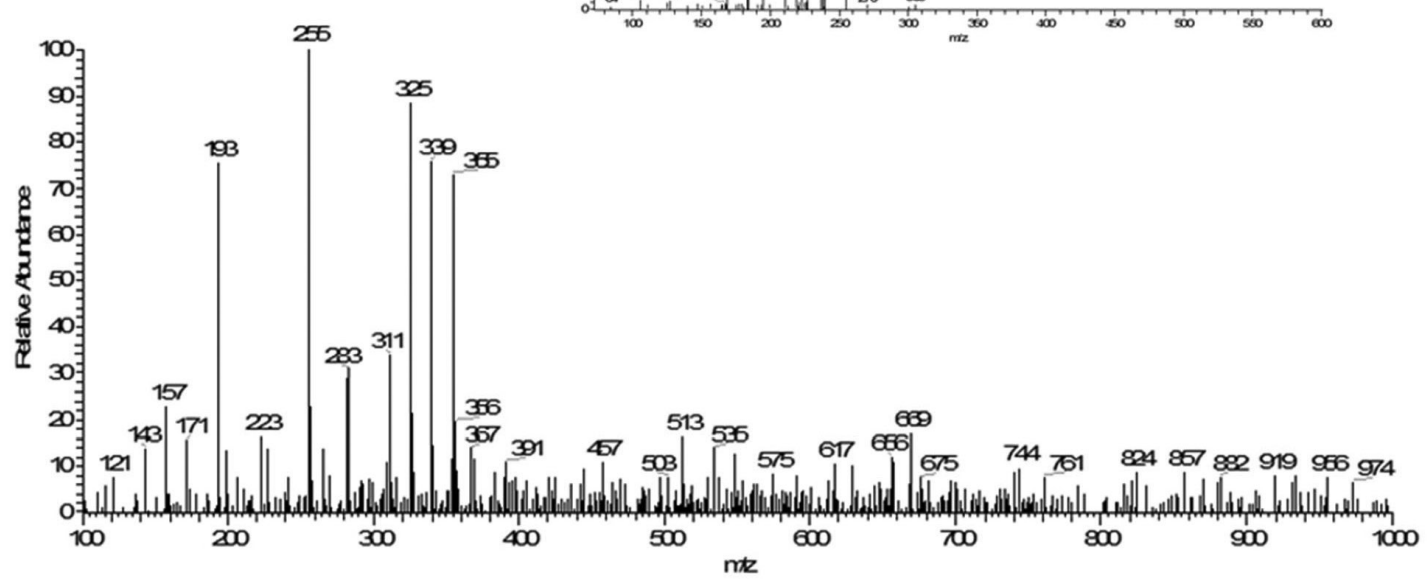

Figure 2. Representation of the spectra (a) (+)PS-MS and (b) (-)PS-MS from a sample of pequi pericarp flour. 
Table 2. Compounds identified in pequi pericarp flour extracts by (+)PS-MS

\begin{tabular}{|c|c|c|c|}
\hline Tentative identification & $m / z$ & MS/MS & Reference \\
\hline L-Arginine & 175 & $\begin{array}{c}70,116 \\
129\end{array}$ & $\begin{array}{l}\text { Gogichaeva et al. }{ }^{48} \\
\text { Özcan and Şenyuva }\end{array}$ \\
\hline Crisoeriol & 301 & 286 & Abu-Reidah et al..$^{50}$ \\
\hline Gallocatechin & 307 & 289 & Fraser et al..$^{51}$ \\
\hline Rhamnetin & 317 & 165 & Abu-Reidah et al..$^{50}$ \\
\hline Sucrose & 365 & 203 & Guo et al..$^{52}$ \\
\hline Ellagic acid xyloside & 435 & 303 & Lee et $a l .^{53}$ \\
\hline Delfinidine-3-glycoside & 465 & 303 & $\begin{array}{l}\text { Flores et al. }{ }^{54} \\
\text { Silva } \text { et al. } .^{55}\end{array}$ \\
\hline Pelargonidin 3-rutinoside & 579 & 433 & Silva et al. ${ }^{55}$ \\
\hline
\end{tabular}

PS-MS: paper spray mass spectrometry.

3-glycoside and pelargonidin 3-rutinoside) were identified.

Among the compounds identified in the extracts of pequi pericarp flours in the present study, sucrose was previously identified in pequi fruits by Marx et al. ${ }^{56}$ by gas chromatography coupled to mass spectrometry. In addition, Leão et al. ${ }^{1}$ identified the presence of ellagic acid, in its non-glycosylated form, in pequi pericarp flours by highperformance liquid chromatography (HPLC-MS).

\section{Fingerprints obtained in negative ionization mode}

The possible compounds identified through the fingerprints on the (-)PS-MS are shown in Table 3.

Organic acids, sugars, phenolic acids, flavonoids, coumarins and tannins were identified in the flours of the pequi pericarp.

Among the organic acids identified are malic $(\mathrm{m} / \mathrm{z}, 115)$, quinic $(\mathrm{m} / \mathrm{z}, 191)$ and ricinoleic $(\mathrm{m} / \mathrm{z}, 297)$ acids, of which quinic acid had already been identified in the pequi fruit using mass spectrometry with electrospray ionization (ESI-MS). ${ }^{60}$

In the present study, several phenolic acids previously identified in the pequi fruit were detected, among them are protocatechuic $(\mathrm{m} / \mathrm{z} / 153)$, gallic $(\mathrm{m} / \mathrm{z} 169)$, caffeic $(\mathrm{m} / \mathrm{z}, 179)$, ferulic $(\mathrm{m} / \mathrm{z}, 193)$ and ellagic deoxyhexoside $(\mathrm{m} / \mathrm{z}, 447)$ acids. $^{72,73} p$-Coumaric and ellagic acids have also been identified in pequi by Machado $\mathrm{et} \mathrm{al.}{ }^{74}$ and were found in the present study in its glycosylated forms (hexoside $p$-coumaric acid $(\mathrm{m} / \mathrm{z} 325)$ and ellagic hexoside galloyl $(\mathrm{m} / \mathrm{z} 615))$.

Various flavonoids have also been identified in the pequi pericarp flours, compounds of the flavonoid subclass predominating, such as taxifolin $(\mathrm{m} / \mathrm{z} 303)$, isorhamnetin $(\mathrm{m} / \mathrm{z} 315)$, quercetin arabinoside $(\mathrm{m} / \mathrm{z} 433)$, isoquercitrin $(\mathrm{m} / \mathrm{z}$ 463), quercetin-3-O-arabinoglycoside $(\mathrm{m} / \mathrm{z}, 595)$ and myricetin galloyl hexoside $(\mathrm{m} / \mathrm{z}, 631)$. Alves et al. ${ }^{75}$ have already identified the presence of isoquercitrin and quercetin in the pequi fruit using HPLC.

The ion with $m / z, 281$ possibly corresponds to the flavone luteolin, previously identified in the pequi fruit by Ferreira ${ }^{73}$ by HPLC-HRMS (high performance liquid chromatography-high resolution mass spectrometry). In addition to these flavonoids, the flavonone pinocembrin $(\mathrm{m} / \mathrm{z} 255)$, the isoflavone formononetin $(\mathrm{m} / \mathrm{z} 267)$, and the flavones baicalein $(\mathrm{m} / \mathrm{z}, 269)$ and vitexin $(\mathrm{m} / \mathrm{z}, 431)$ were identified.

Recent studies ${ }^{76,77}$ have shown that flavonoids perform several important functions, such as antioxidant, antiinflammatory, antihypertensive and anti-diabetic activity.

The ion with $\mathrm{m} / \mathrm{z} 161$ corresponds to umbelliferone coumarin and was confirmed after its fragmentation $(\mathrm{m} / z, 117$ and 133). The ion $\mathrm{m} / z 633$ corresponds to the hydrolysable tannin strictinin.

The chemical compounds identified in the pequi pericarp have several beneficial health functions, such as high antioxidant capacity, anti-inflammatory, antibacterial, antifungal, antiviral and anticancer actions, demonstrating the functional potential of this residue for use in the development of new products with high nutritional value. ${ }^{76,77}$

\section{Principal component analysis (PCA)}

Principal component analysis was performed using mass spectra in the positive and negative ionization modes. The models were constructed by selecting two principal components (PC1 and PC2), which explained 50.69\% $((+)$ PS-MS $)$ and $52.75 \%((-)$ PS-MS) of the total data variability. In both ionization modes, the PCA demonstrated that there was no chemical variation among the fruits from the studied micro-regions (Figure 3).

The absence of differentiation between the samples can be justified by the fact that the municipalities are close to each other (distance of $36 \mathrm{~km}$ between Sete Lagoas and Paraopeba, $87 \mathrm{~km}$ between Paraopeba and Felixlândia and $105 \mathrm{~km}$ from Sete Lagoas and Felixlândia), contributing to similarity as to soil, temperature, stress factors and sun exposure. According to Telles et al..$^{78}$ the best sampling strategy for higher genetic variability is to use the largest number of subpopulations at a distance greater than $120 \mathrm{~km}$.

\section{Total phenolic compounds and antioxidant capacity}

The levels of total phenolic compounds and the antioxidant capacity of the pequi pericarp flour pools in each city before and after the in vitro simulated digestion process are shown in Table 4.

The phenolic compounds content and antioxidant 
Table 3. Compounds identified in pequi pericarp flour extracts by (-)PS-MS

\begin{tabular}{|c|c|c|c|}
\hline Tentative identification & $\mathrm{m} / \mathrm{z}$ & MS/MS & Reference \\
\hline Malic acid & 115 & 71 & Wang et al. ${ }^{57}$ \\
\hline Salicylic acid & 137 & 93 & Friščić et al. ${ }^{58}$ \\
\hline Vanillin & 151 & 123,136 & Martini et $a l^{59}$ \\
\hline Protocatechuic acid & 153 & 109 & $\begin{array}{l}\text { Abu-Reidah } \text { et al. } \\
\text { Friščić } \text { et al. } .^{58}\end{array}$ \\
\hline Umbelliferone & 161 & 117,133 & Abu-Reidah et al..$^{50}$ \\
\hline Gallic acid & 169 & 97,125 & $\begin{array}{l}\text { Wang et al. } .^{57} \\
\text { Roesler } \text { et } a l^{60}\end{array}$ \\
\hline Caffeic acid & 179 & 135 & $\begin{array}{l}\text { Friščić et al. }{ }^{58} \\
\text { Chen } \text { et al. }\end{array}$ \\
\hline Quinic acid & 191 & $111,127,173$ & Du et al..$^{62}$ \\
\hline Ferulic acid & 193 & 149 & $\begin{array}{l}\text { Wang et al. }{ }^{57} \\
\text { Friščić et al. } .^{58}\end{array}$ \\
\hline Synapic acid & 223 & 179,208 & $\begin{array}{l}\text { Friščić et al. }{ }^{58} \\
\text { Hamed et al. }{ }^{63}\end{array}$ \\
\hline Hydroxybenzyl malic acid (eucomic acid) & 239 & $149,177,179,195$ & Abu-Reidah et al. ${ }^{64}$ \\
\hline Pinocembrin & 255 & 169,211 & Gobbo-Neto and Lopes ${ }^{65}$ \\
\hline Formononetin & 267 & 208,223 & Abu-Reidah et $_{\text {al. }}{ }^{64}$ \\
\hline Baicalein & 269 & 179,251 & Du et al..$^{62}$ \\
\hline Luteolin & 285 & $\begin{array}{c}133,197,213,223,239,241,243 \\
257,267\end{array}$ & $\begin{array}{l}\text { Annapurna et al. } .^{66} \\
\text { Kang et al. }{ }^{67}\end{array}$ \\
\hline Catechin & 289 & 245 & Kang et al. ${ }^{67}$ \\
\hline Ricinoleic acid & 297 & 183 & Wang et al..$^{57}$ \\
\hline Taxifolin & 303 & $125,199,285$ & Kang et al. ${ }^{67}$ \\
\hline Isorhamnetin & 315 & 300 & Kang et al..$^{67}$ \\
\hline Hexoside $p$-coumaric acid & 325 & 119 & Kajdžanoska et al. ${ }^{68}$ \\
\hline Galloyl glucose isomer & 331 & 125,169 & Martini et al..$^{59}$ \\
\hline Caffeoylquinic acid & 353 & 179,191 & Kang et al. ${ }^{67}$ \\
\hline 3-O-Feruloylquinic acid & 367 & 149,193 & Alakolanga et al. ${ }^{69}$ \\
\hline Hexose or sucrose & 377 & 341 & Chen et al. ${ }^{61}$ \\
\hline Vitexin & 431 & 311,341 & $\begin{array}{l}\text { Wang et al. } .^{57} \\
\text { Wang et al. } .^{57}\end{array}$ \\
\hline Quercetin arabinoside & 433 & 300 & Abu-Reidah et al..$^{50}$ \\
\hline Ellagic acid deoxyhexoside & 447 & 301 & Oliveira et al..$^{70}$ \\
\hline Hexoside catechin & 451 & 289 & Kang et al. ${ }^{67}$ \\
\hline Isoquercitrin & 463 & 301 & Friščić et al. ${ }^{58}$ \\
\hline (Epi) galocatechin hexose & 467 & 261,423 & Abu-Reidah et al. ${ }^{64}$ \\
\hline Chicoric acid derived & 473 & 293 & Chen et al. ${ }^{61}$ \\
\hline Galloyl hexose derivative & 505 & 169,331 & Abu-Reidah et $a l .50$ \\
\hline Caffeoylferuloylquinic acid & 529 & 193 & Gobbo-Neto and Lopes ${ }^{65}$ \\
\hline (Epi)catechin-(Epi)catechin (procyanidin B IV) & 577 & 407,425 & Abu-Reidah et $_{\text {al. }}{ }^{64}$ \\
\hline Quercetin-3-O-arabinoglycoside & 595 & 433 & Abu-Reidah et al..$^{64}$ \\
\hline Ellagic acid galloyl hexoside & 615 & 301,463 & Teixeira et $_{\text {al. }}{ }^{11}$ \\
\hline Myricetin galloyl hexoside & 631 & 316,479 & Teixeira et $_{\text {al. }}{ }^{71}$ \\
\hline Strictinin & 633 & 301,481 & Teixeira et $_{\text {al. }}{ }^{71}$ \\
\hline
\end{tabular}

PS-MS: paper spray mass spectrometry.

capacity of pequi pericarp flours differed significantly $(p<0.05)$ among the cities, and the sample content from Sete Lagoas was statistically higher compared to the other regions. The data obtained in the present study for phenolic compounds were superior to those of Monteiro et al.,$^{4}$ who reported 7,200 mg GAE $100 \mathrm{~g}^{-1}$ in aqueous extract and 7,900 mg GAE $100 \mathrm{~g}^{-1}$ in hydroethanolic extract of pequi pericarp from Montes Claros.
The differences between the results found in the present study and these others may be related to the level of fruit maturation, geographic location, soil, climate, predator attack and ultraviolet radiation, among others. ${ }^{79}$ The ripening phase of the pequi begins in the $9^{\text {th }}$ week after the start of fruiting and the ideal fruit harvesting period is in the $12^{\text {th }}$ week, when ripening has finished and the fruit has reached the maximum levels of antioxidant compounds such as $\beta$-carotene and 

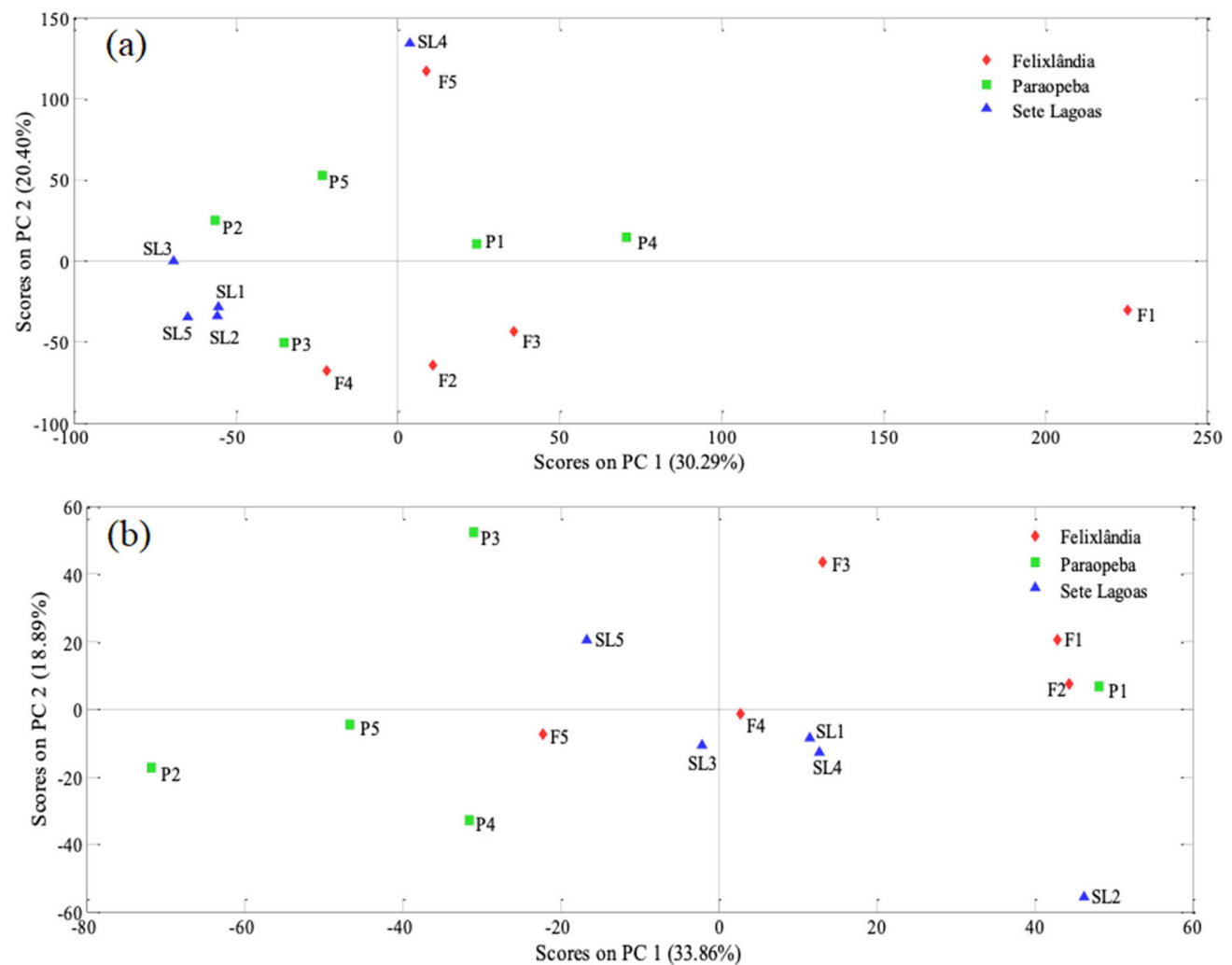

Figure 3. PC1 and PC2 scores in positive (a) and negative (b) ionization mode. SL: Sete Lagoas; P: Paraopeba; F: Felixlândia.

Table 4. Total phenolic compounds and antioxidant capacity of pequi pericarp flours before and after simulated in vitro digestion

\begin{tabular}{|c|c|c|c|c|}
\hline \multirow{2}{*}{ Parameter } & \multirow{2}{*}{ Digestion } & \multicolumn{3}{|c|}{ Samples } \\
\hline & & Sete Lagoas & Paraopeba & Felixlândia \\
\hline \multirow{2}{*}{ Total phenolic compounds / (mg GAE $100 \mathrm{~g}^{-1}$ ) } & before & $12374.87^{\mathrm{aA}} \pm 9.40$ & $8512.79^{\mathrm{bA}} \pm 18.18$ & $11507.63^{\mathrm{cA}} \pm 17.03$ \\
\hline & after & $19666.99^{\mathrm{aB}} \pm 20.82$ & $14334.93^{\mathrm{bB}} \pm 15.69$ & $15910.11^{\mathrm{cB}} \pm 19.41$ \\
\hline \multirow{2}{*}{ ABTS / $\left(\mu \mathrm{M}\right.$ trolox $\left.\mathrm{g}^{-1}\right)$} & before & $1153.50^{\mathrm{aA}} \pm 5.23$ & $1080.03^{\mathrm{bA}} \pm 2.97$ & $1105.53^{\mathrm{cA}} \pm 2.58$ \\
\hline & after & $4811.65^{\mathrm{aB}} \pm 9.13$ & $2859.25^{\mathrm{bB}} \pm 15.50$ & $3497.98^{\mathrm{cB}} \pm 18.39$ \\
\hline \multirow{2}{*}{ FRAP / $\left(\mu \mathrm{M}\right.$ ferrous sulfate $\left.\mathrm{g}^{-1}\right)$} & before & $2081.41^{\mathrm{aA}} \pm 15.34$ & $1419.42^{\mathrm{bA}} \pm 17.82$ & $1953.82^{\mathrm{cA}} \pm 7.54$ \\
\hline & after & $3023.74^{\mathrm{aB}} \pm 22.49$ & $2208.47^{\mathrm{bB}} \pm 13.84$ & $2829.71^{\mathrm{cB}} \pm 17.82$ \\
\hline \multirow{2}{*}{$\mathrm{DPPH} /\left(\mu \mathrm{M} \mathrm{TE} \mathrm{g}^{-1}\right)$} & before & $1541.77^{\mathrm{aA}} \pm 15.54$ & $1435.69^{\mathrm{bA}} \pm 5.43$ & $1299.38^{\mathrm{cA}} \pm 17.37$ \\
\hline & after & $2150.65^{\mathrm{aB}} \pm 13.47$ & $1964.16^{\mathrm{bB}} \pm 15.46$ & $1955.93^{\mathrm{bB}} \pm 22.61$ \\
\hline
\end{tabular}

GAE: gallic acid equivalent; ABTS: 2,21-azino-bis(3-ethyl-benzothiazoline-6-sulfonic acid); FRAP: ferric reducing antioxidant power; DPPH: 2,2-diphenyl1-picryl-hydrazil; TE: Trolox equivalent. Averages followed by the same lowercase letter on the same line do not differ, using the Tukey's test $(\alpha=0.05$; $n=3)$. Means followed by the same capital letter in the same column do not differ, using the Tukey's test $(\alpha=0.05 ; n=3)$.

vitamin $C{ }^{80}$ Thus, the pequi collection period directly influences the content of bioactive compounds present in the fruit, as well as the chosen solvent which must present polarity similar to the target phenolic compounds. ${ }^{81}$

Comparing the contents of phenolic compounds in the studied flours with those of wastes from other fruits, the values of the data from this study were higher than those obtained from pear peel, ${ }^{82}$ peach ${ }^{83}$ and baru. ${ }^{84}$ In addition, the pequi pericarp flour samples showed higher antioxidant capacity than that of pineapple, cashew, passion fruit and mango flours ${ }^{85}$ Considering that the amount of waste from the pequi is higher than the amount of the waste from other fruits such as pear, peach and mango, and that the pequi pericarp has higher phenolic compound contents than that found in the residue of these fruits, the use of this waste shows to be even more advantageous.

The phenolic compounds content obtained in the present study were also much higher than that described for the pulp (209 mg GAE $100 \mathrm{~g}^{-1}$ ) and pequi seed (122 mg GAE $\left.100 \mathrm{~g}^{-1}\right){ }^{86}$ This result corroborates other studies $^{82,84,87,88}$ that compared different parts of fruits and showed that the phenolic compounds are preferentially located in the peels and seeds and, in smaller amounts, in the pulp. 
After the in vitro simulated digestion process, an increase in phenolic compounds ranging from 38.26 to $68.39 \%$ was observed. Due to the fact that the phenolic compounds are more bioaccessible, the antioxidant capacity of the samples was also higher after the simulated in vitro digestion process. Corroborating the result obtained in the present study, Su et al..$^{89}$ and Gullon et al..$^{90,91}$ observed an increase in antioxidant capacity, after in vitro digestion, in samples of citrus peels, apple pomace flour and pomegranate peel flour, respectively.

The results obtained for total phenolic compounds and for antioxidant capacity by the ABTS, FRAP and DPPH methods after the in vitro digestion process demonstrated a significant increase in the antioxidant capacity of pequi pericarp flours. These results suggest that several changes occur in phenolic compounds, such as the interaction with other components of the food matrix released during gastrointestinal digestion, such as some minerals or proteins, as well as modification of the chemical structure or increased solubility, which can affect the bioaccessibility of the phenolic compounds. ${ }^{90}$ Furthermore, phenolic compounds are normally present in food in the form of glycosides linked to the food matrix. Mainly as a result of digestion and $\mathrm{pH}$ change, these compounds are hydrolyzed and released from the food matrix, ${ }^{92}$ which corroborates the result of improvement in this antioxidant capacity.

\section{Conclusions}

Pequi pericarp flours had higher levels of protein, ash and total dietary fiber compared to data presented in the literature for the fruit pulp. The analysis of the fingerprints allowed the identification of 46 chemical compounds present in the samples; flavonoids, which exert several beneficial health effects were in predominance. The PCA demonstrated there was no chemical variation among the fruits from the studied micro-regions. Pequi pericarp flours had higher levels of phenolic compounds and antioxidant capacity than those described in the literature for flours from other fruit wastes such as pineapple, cashew, passion fruit and mango, and also higher than those described for pequi pulp. In addition, the increased bioaccessibility of phenolic compounds demonstrated the antioxidant potential of pequi pericarp flours that could be used in the development of new products by the food industry, capable of reducing the risk of developing diseases caused by oxidative stress.

\section{Acknowledgments}

The authors would like to thank Coordenação de Aperfeiçoamento de Pessoal de Nível Superior (CAPES,
88882.380959/2019-01) for the financial support, Universidade Federal de Minas Gerais (UFMG) and PróReitoria de Pesquisa (PRPq, UFMG) for the support.

\section{Author Contributions}

Bárbara O. Santos was responsible for the conceptualization, formal analysis, investigation, methodology, data curation, project administration, writing an original draft, and writing review and editing; Maurício Tanigaki for the formal analysis and help writing an original draft; Mauro R. Silva for the methodology, validation, data curation, and software; Ana Luiza C. C. Ramos for the formal analysis and help writing review and editing; Renata A. Labanca and Rodinei Augusti for the supervision and resources; Júlio O. F. Melo, Jacqueline A. Takahashi and Raquel L. B. de Araújo for the conceptualization, writing review and editing, formal analysis funding acquisition, resources, supervision and project administration.

\section{References}

1. Leão, D. P.; Franca, A. S.; Oliveira, L. S.; Bastos, R.; Coimbra, M. A.; Food Chem. 2017, 225, 146.

2. IBGE; Produção da Extração Vegetal e da Silvicultura, https:// sidra.ibge.gov.br/Tabela/289, accessed in January 2022.

3. Amorim, D. J.; Rezende, H. C.; Oliveira, É. L.; Almeida, I. L. S.; Coelho, N. M. M.; Matos, T. N.; Araújo, C. S. T.; J. Braz. Chem. Soc. 2016, 27, 616.

4. Monteiro, S. S.; Silva, R. R.; Martins, S. C.; Barin, J. S.; Rosa, C. S.; Int. Food Res. J. 2015, 22, 1985.

5. Couto, E. M.: Utilização da Farinha de Casca de Pequi (Caryocar brasiliense Camb.) na Elaboração de Pão de Forma; MSc Dissertation, Universidade Federal de Lavras, Lavras, Brazil, 2007, available at http://repositorio.ufla.br/ jspui/bitstream/1/2870/1/DISSERTA\%C3\%87\%C3\%83O_\%20 Utiliza $\%$ C3\%A7\%C3\%A3o\%20da\%20farinha $\% 20 \mathrm{de} \% 20$ casca $\% 20 \mathrm{de} \% 20$ pequi $\% 20 \% 28$ Caryocar $\% 20$ brasiliense $\% 20$ Camb.\%29\%20na\%20elabora\%C3\%A7\%C3\%A3o\%20de\%20 p\%C3\%A3o\%20de\%20forma.pdf, accessed in January 2022.

6. Soares Jr., M. S.; Reis, R. C.; Bassinello, P. Z.; Lacerda, D. B. C.; Koakuzu, S. N.; Caliari, M.; Pesqui. Agropecu. Trop. 2009, 39, 98.

7. Leão, D. P.; Botelho, B. G.; Oliveira, L. S.; Franca, A. S.; LWT--Food Sci. Technol. 2018, 87, 575.

8. Moreira, R. V.; Costa, M. P.; Castro, V. S.; Paes, C. E.; Mutz, Y. S.; Frasão, B. S.; Mano, S. B.; Conte-Junior, C. A.; J. Dairy Sci. 2019, 102, 2966.

9. Huber, K.; Queiroz, J. H.; Moreira, A. V. B.; Ribeiro, S. M. R.; Rev. Bras. Tecnol. Agroind. 2012, 6, 640.

10. de Oliveira, F. C.; Marques, T. R.; Machado, G. H. A.; de Carvalho, T. C. L.; Caetano, A. A.; Batista, L. R.; Corrêa, A. D.; Braz. J. Food Technol. 2018, 21, e2017108. 
11. Celestino, S. M. C.; Princípios de Secagem de Alimentos; Embrapa Cerrados: Planaltina, DF, 2010.

12. Soquetta, M. B.; Stefanello, F. S.; Huerta, K. M.; Monteiro, S. S.; da Rosa, C. S.; Terra, N. N.; Food Chem. 2016, 199, 471.

13. Sindhi, V.; Gupta, V.; Sharma, K.; Bhatnagar, S.; Kumari, R.; Dhaka, N.; J. Pharm. Res. 2013, 7, 828.

14. Arrozi, A. P.; Ngah, W. Z. W.; Yusof, Y. A. M.; Damanhuri, M. H. A.; Makpol, S.; Int. J. Neurosci. 2017, 127, 218.

15. Tagliazucchi, D.; Verzelloni, E.; Bertolini, D.; Conte, A.; Food Chem. 2010, 120, 599.

16. Stanisavljević, N.; Samardžić, J.; Janković, T.; Šavikin, K.; Mojsin, M.; Topalović, V.; Stevanović, M.; Food Chem. 2015, 175, 516.

17. Galanakis, C. M.; Drago, S. R.; Nutraceutical and Functional Food Components - Effects of Innovative Processing Techniques, $1^{\text {st }}$ ed.; Galanakis, C., ed.; Academic Press: Chennai, India, 2016, 5.

18. Deng, J.; Yang, Y.; Anal. Chim. Acta 2013, 785, 82.

19. Zhi-Ping, Z.; Xiao-Ning, L.; Ya-Jun, Z.; Chin. J. Anal. Chem. 2014, 42, 145

20. Silva, M. R.; Freitas, L. G.; Souza, A. G.; Araújo, R. L. B.; Lacerda, I. C. A.; Pereira, H. V.; Augusti, R.; Melo, J. O. F.; J. Braz. Chem. Soc. 2019, 30, 1034.

21. Teodoro, J. A. R.; Pereira, H. V.; Sena, M. M.; Piccin, E.; Zacca, J. J.; Augusti, R.; Food Chem. 2017, 237, 1058.

22. de Oliveira Jr., A. H.; Mendonça, H. O. P.; Guedes, M. N. S.; Fagundes, M. C. P.; Ramos, A. L. C. C.; Augusti, R.; de Araújo, R. L. B.; Reina, L. D. C. B.; Melo, J. O. F. In Avanços em Ciência e Tecnologia de Alimentos; Verruck, S., org.; Editora Científica: Guarujá, 2020, p. 338-353.

23. Pereira, I.; Rodrigues, S. R. M.; de Carvalho, T. C.; Carvalho, V. V.; Lobón, G. S.; Bassane, J. F. P.; Domingos, E.; Romão, W.; Augusti, R.; Vaz, B. G.; Anal. Methods 2016, 8, 6023.

24. Silva, E.; Augusti, R.; Melo, J.; Takahashi, J.; Araújo, R.; Quim. Nova 2020, 43, 319.

25. Di Donna, L.; Taverna, D.; Indelicato, S.; Napoli, A.; Sindona, G.; Mazzotti, F.; Food Chem. 2017, 229, 354.

26. e Loyola, A. C. F.; Silva, V. D. M.; Silva, M. R.; Rodrigues, C. G.; dos Santos, A. N.; Melo, J. O. F.; Augusti, R.; Fante, C. A.; J. Braz. Chem. Soc. 2021, 32, 953.

27. Silva, M.; Freitas, L.; Mendonça, H.; Souza, A.; Pereira, H.; Augusti, R.; Lacerda, I.; Melo, J.; Araújo, R.; Quim. Nova 2021, 44, 129.

28. Silva, V. D. M.; Macedo, M. C. C.; Santos, A. N.; Silva, M. R.; Augusti, R.; Lacerda, I. C. A.; Melo, J. O. F.; Fante, C. A.; Rapid Commun. Mass Spectrom. 2020, 34, e8883.

29. Campelo, F. A.; Henriques, G. S.; Simeone, M. L. F.; Queiroz, V. A. V.; Silva, M. R.; Augusti, R.; Melo, J. O. F.; Lacerda, I. C. A.; Araújo, R. L. B.; J. Braz. Chem. Soc. 2020, 31, 788.

30. Pereira, H. V.; Amador, V. S.; Sena, M. M.; Augusti, R.; Piccin, E.; Anal. Chim. Acta 2016, 940, 104.

31. Garrett, R.; Rezende, C. M.; Ifa, D. R.; Anal. Methods 2013, 5, 5944.
32. Mazzotti, F.; Di Donna, L.; Taverna, D.; Nardi, M.; Aiello, D.; Napoli, A.; Sindona, G.; Int. J. Mass Spectrom. 2013, 352, 87.

33. Sneha, M.; Dulay, M. T.; Zare, R. N.; Int. J. Mass Spectrom. 2017, 418, 156.

34. Association of Official Analytical Chemists (AOAC); Official Methods of Analysis, 21 ${ }^{\text {th }}$ ed.; AOAC: Gaithersburg, Maryland, USA, 2019.

35. Rufino, M. S. M.; Alves, R. E.; de Brito, E. S.; Pérez-Jiménez, J.; Saura-Calixto, F.; Mancini-Filho, J.; Food Chem. 2010, 121, 996.

36. García, Y. M.; Ramos, A. L. C. C.; de Oliveira Jr., A. H.; de Paula, A. C. C. F. F.; de Melo, A. C.; Andrino, M. A.; Silva, M. R.; Augusti, R.; de Araújo, R. L. B.; de Lemos, E. E. P.; Melo, J. O. F.; Molecules 2021, 26, 7206.

37. Singleton, V. L.; Orthofer, R.; Lamuela-Raventós, R. M.; Methods Enzymol. 1999, 418, 152.

38. Association of Official Analytical Chemists (AOAC); Official Methods of Analysis, $19^{\text {th }}$ ed.; AOAC: Washington D.C., USA, 2012.

39. Minekus, M.; Alminger, M.; Alvito, P.; Ballance, S.; Bohn, T.; Bourlieu, C.; Carrière, F.; Boutrou, R.; Corredig, M.; Dupont, D.; Dufour, C.; Egger, L.; Golding, M.; Karakaya, S.; Kirkhus, B.; Le Feunteun, S.; Lesmes, U.; Macierzanka, A.; Mackie, A.; Marze, S.; McClements, D. J.; Ménard, O.; Recio, I.; Santos, C. N.; Singh, R. P.; Vegarud, G. E.; Wickham, M. S. J.; Weitschies, W.; Brodkorb, A.; Food Funct. 2014, 5, 1113.

40. Redmond, W. E.; Excel 2010; Microsoft, 2010.

41. MATLAB, version 7.10.0.499; MathWorks, Natick, MA, USA, 2009.

42. PLS Toolbox, version 5.2.2; Eigenvectors Research, Manson, WA, USA, 2009.

43. Agência Nacional de Vigilância Sanitária (ANVISA); Regulamento Técnico para Produtos de Cereais, Amidos, Farinhas e Farelos; Ministério da Saúde: Brasília, DF, 2005, available at https://bvsms.saude.gov.br/bvs/saudelegis/ anvisa/2005/rdc0263_22_09_2005.html, accessed in January 2022.

44. Bernaud, F. S. R.; Rodrigues, T. C.; Arq. Bras. Endocrinol. Metabol. 2013, 57, 397.

45. Zhao, G.; Zhang, R.; Dong, L.; Huang, F.; Tang, X.; Wei, Z.; Zhang, M.; LWT--Food Sci. Technol. 2018, 87, 450.

46. Agência Nacional de Vigilância Sanitária (ANVISA); Regulamento Técnico sobre Informação Nutricional Complementar; Ministério da Saúde: Brasília, DF, 2012, available at https://bvsms.saude.gov.br/bvs/saudelegis/anvisa/2012/ rdc0054_12_11_2012.html, accessed in January 2022.

47. Silva, C. A. A.; Fonseca, G. G.; Food Sci. Biotechnol. 2016, 25 , 1225

48. Gogichaeva, N. V.; Williams, T.; Alterman, M. A.; J. Am. Soc. Mass Spectrom. 2007, 18, 279. 
49. Özcan, S.; Şenyuva, H. Z.; J. Chromatogr. A 2006, 1135, 179.

50. Abu-Reidah, I. M.; Ali-Shtayeh, M. S.; Jamous, R. M.; ArráezRomán, D.; Segura-Carretero, A.; Food Chem. 2015, 166, 179.

51. Fraser, K.; Collette, V.; Hancock, K. R.; J. Agric. Food Chem. 2016, 64, 6676.

52. Guo, Y.; Gu, Z.; Liu, X.; Liu, J.; Ma, M.; Chen, B.; Wang, L.; Phytochem. Anal. 2017, 28, 344.

53. Lee, J.-H.; Johnson, J. V.; Talcott, S. T.; J. Agric. Food Chem. 2005, 53, 6003 .

54. Flores, G.; Dastmalchi, K.; Paulino, S.; Whalen, K.; Dabo, A. J.; Reynertson, K. A.; Foronjy, R. F.; D’ Armiento, J. M.; Kennelly, E. J.; Food Chem. 2012, 134, 1256.

55. da Silva, N. A.; Rodrigues, E.; Mercadante, A. Z.; de Rosso, V. V.; J. Agric. Food Chem. 2014, 62, 5072.

56. Marx, F.; Andrade, E. H. A.; Maia, J. G.; Z. Lebensm.-Unters. -Forsch. A 1997, 204, 442.

57. Wang, J.; Jia, Z.; Zhang, Z.; Wang, Y.; Liu, X.; Wang, L.; Lin, R.; Molecules 2017, 22, 476.

58. Friščić, M.; Bucar, F.; Pilepić, K. H.; J. Mass Spectrom. 2016, $51,1211$.

59. Martini, S.; Conte, A.; Tagliazucchi, D.; Food Res. Int. 2018, $112,1$.

60. Roesler, R.; Catharino, R. R.; Malta, L. G.; Eberlin, M. N.; Pastore, G.; Food Chem. 2007, 104, 1048.

61. Chen, H.-J.; Inbaraj, B. S.; Chen, B.-H.; Int. J. Mol. Sci. 2012 , $13,260$.

62. Du, J.; Teng, R.-J.; Lawrence, M.; Guan, T.; Xu, H.; Ge, Y.; Shi, Y.; Butko, P.; PLoS One 2012, 7, e33991.

63. Hamed, A. I.; Said, R. B.; Kontek, B.; Al-Ayed, A. S.; Kowalczyk, M.; Moldoch, J.; Stochmal, A.; Olas, B.; Food Res. Int. 2016, 85, 282.

64. Abu-Reidah, I. M.; Contreras, M. M.; Arráez-Román, D.; Fernández-Gutiérrez, A.; Segura-Carretero, A.; Electrophoresis 2014, 35, 1571.

65. Gobbo-Neto, L.; Lopes, N. P.; J. Agric. Food Chem. 2008, 56, 1193.

66. Annapurna, H. V.; Apoorva, B.; Ravichandran, N.; Arun, K. P.; Brindha, P.; Swaminathan, S.; Vijayalakshmi, M.; Nagarajan, A.; J. Mol. Graphics Modell. 2013, 39, 87.

67. Kang, J.; Price, W. E.; Ashton, J.; Tapsell, L. C.; Johnson, S.; Food Chem. 2016, 211, 215.

68. Kajdžanoska, M.; Gjamovski, V.; Stefova, M.; Maced. J. Chem. Chem. Eng. 2010, 29, 181.

69. Alakolanga, A. G. A. W.; Siriwardane, A. M. D. A.; Kumar, N. S.; Jayasinghe, L.; Jaiswal, R.; Kuhnert, N.; Food Res. Int. 2014, 62, 388.

70. Oliveira, A. L.; Destandau, E.; Fougère, L.; Lafosse, M.; Food Chem. 2014, 145, 522.

71. Teixeira, J.; Gaspar, A.; Garrido, E. M.; Garrido, J.; Borges, F.; Biomed Res. Int. 2013, 2013, article ID 251754.
72. Chisté, R. C.; Mercadante, A. Z.; J. Agric. Food Chem. 2012. 60,5884 .

73. Ferreira, C. M.: Análise Química de Extratos de Caryocar brasiliense com Potencial Antioxidante; MSc Dissertation, Universidade Federal de Goiás, Goiânia, Brazil, 2019, available at https://repositorio.bc.ufg.br/tede/handle/tede/9699, accessed in January 2022.

74. Machado, M. T. C.; Mello, B. C. B. S.; Hubinger, M. D.; Food Bioprod. Process. 2015, 95, 304.

75. Alves, A. M.; Dias, T.; Hassimotto, N. M. A.; Naves, M. M. V.; Food Sci. Technol. 2017, 37, 564.

76. Ikarashi, N.; Toda, T.; Hatakeyama, Y.; Kusunoki, Y.; Kon, R.; Mizukami, N.; Kaneko, M.; Ogawa, S.; Sugiyama, K.; Int. J. Mol. Sci. 2018, 19, 700.

77. Tejada, S.; Pinya, S.; Martorell, M.; Capó, X.; Tur, J. A.; Pons, A.; Sureda, A.; Curr. Med. Chem. 2018, 25, 4929.

78. Telles, M. P. D. C.; Diniz-Filho, J. A. F.; Coelho, A. S. G.; Chaves, L. J.; Rev. Bras. Bot. 2001, 24, 145.

79. Nascimento-Silva, N. R. R.; Mendes, N. S. R.; Silva, F. A.; J. Bioenergy Food Sci. 2020, 7, e2812019JBFS.

80. Rodrigues, L. J.; de Paula, N. R. F.; Pinto, D. M.; Boas, E. V. B. V.; Food Sci. Technol. 2015, 35, 11.

81. Fanali, C.; Tripodo, G.; Russo, M.; Posta, S. D.; Pasqualetti, V.; De Gara, L.; Electrophoresis 2018, 39, 1683.

82. Li, X.; Wang, T.; Zhou, B.; Gao, W.; Cao, J.; Huang, L.; Food Chem. 2014, 152, 531.

83. Liu, H.; Cao, J.; Jiang, W.; LWT--Food Sci. Technol. 2015, 63, 1042.

84. Santiago, G. L.; de Oliveira, I. G.; Horst, M. A.; Naves, M. M. V.; Silva, M. R.; Food Sci. Technol. 2018, 38, 244.

85. Infante, J.; Selani, M. M.; Toledo, N. M. V.; Silveira-Diniz, M. F.; Alencar, S. M.; Spoto, M. H. F.; Braz. J. Food Nutr. 2013, $24,87$.

86. de Lima, A.; e Silva, A. M. O.; Trindade, R. A.; Torres, R. P.; Mancini-Filho, J.; Rev. Bras. Frutic. 2007, 29, 695.

87. Contreras-Calderón, J.; Calderón-Jaimes, L.; Guerra-Hernández, E.; García-Villanova, B.; Food Res. Int. 2011, 44, 2047.

88. Wang, S. Y.; Camp, M. J.; Ehlenfeldt, M. K.; Food Chem. 2012, $132,1759$.

89. Su, D.; Liu, H.; Zeng, Q.; Qi, X.; Yao, X.; Zhang, J.; Int. J. Food Sci. Technol. 2017, 52, 2471.

90. Gullon, B.; Pintado, M. E.; Barber, X.; Fernández-López, J.; Pérez-Álvarez, J. A.; Viuda-Martos, M.; Food Res. Int. 2015, $78,169$.

91. Gullon, B.; Pintado, M. E.; Fernández-López, J.; Pérez-Álvarez, J. A.; Viuda-Martos, M.; J. Funct. Foods 2015, 19, 617.

92. Rodríguez-Roque, M. J.; Rojas-Graü, M. A.; Elez-Martínez, P.; Martín-Belloso, O.; Food Chem. 2013, 136, 206.

Submitted: June 30, 2021

Published online: February 1, 2022 